Nazek Ibrahim ABDUL FATTAH

\title{
Rereading Aramaic Papyrus
}

(Cowley 15)

Some researchers try to attribute the Aramaic Papyri of the fifth century B. C. found in Elphantine / yeb (Upper Egypt) to the Jewish community live there in the same area at the same time. (In this matter I try here to disprove their claim in accordance with logic and facts, proving that Aramaic Papyri of Elphantine belong absolutely to Arameans of Egypt who composed, scrolled and preserved them.

As Elphantine papyri provide us with data concerning Aramaic speaking community in Upper Egypt, so do the archeological excavations in the area, throwing light upon the papyri.

At the end of $19^{\text {th }}$ century and beginning of $20^{\text {th }}$ century some German and French archeologists carried out excavations in the area which result in finding Khnum Temple. Also a line of houses in "Temple Street" adjacent to Khnum temple in the Aramaic district of Yeb. One of these houses contained three chambers. In one of them was found a huge pile of scrolled papyri written in Aramaic language, while the other two chambers contain Jars full of Aramaic inscriptions (Jars of the same type as those in Thebes in the tombs of $21^{\text {st }}$ up to $26^{\text {th }}$ dynasties).

When German excavators discovered the two walls, the northern and western, of Khnum Temple, and as they proceeded towards the south in the same area where they found Aramaic Papyri they ran into a huge wall of bricks in the direction of East and West. So they inferred that it was the outer wall of than temple (Kraeling, P. 70).

On the basis of this fact it is confirmed now that Khnum Temple was situated in the Aramaic area where the Aramaic Papyri were discovered in Yeb.

Researchers presumed the existence of another temple called Yaho Temple. Excavators proved that the temple presumably situated beside the houses where the Aramaic Papyri were discovered. This could be a proof 
that the Aramaic Papyri were discovered nearby Yaho Temple and not inside.

Rubensohn (German excavator) inferred that there was a street, that is King's Street, He presumed that the Jewish temple was situated at the east of it. Yet, he added "any expectation to discover again "Yaho Temple" in this area failed because it was uprooted (pulled up by roots). Therefore efforts to locate the temple had lost ground". (Honroth \& Others Ausgrabungen P. 30).

Without Previous knowledge of the Gemran assumption concerning the area where Yaho temple is probably existed, Clermont-Ganneau occupied himself with the issue of Yaho Temple and started to search an archaeological basics for the temple in this area. He expressed his mere feeling towards the existence of the temple in a letter to De Vogue (Journal des Savants P. 1.36). However, he did not risk to assure that the Temple was erected there. He believed that Yaho Temple was destructed and the sanctum was destroyed. Hence, he depended on his feeling composing in his mind the legend of a Jewish Temple, around which houses of Jews lied (Kraeling, PP. 73, 76). Kraeling assures that the excavations did not come to any conclusion as regards to the site of any Jewish Temple which remained always under suspicion. He started searching for it in terms like "King's Street" i.e. the "main street", though Rubensohn pinpointed it as the street which runs along the northern wall of Khnum Temple in the Ptolemaic era. Yet, he withdrew the idea as it confirms that in this street there were houses of Arameans where Sayce-Cowley found the Aramaic Papyri. As to his search for the site of Yaho Temple in terms like "the upper side" \& "the lower side", it confirms, in spite of him, that the place belongs to Arameans as it shows the assumption of Cowley that the "upper" refers to south, while the "lower" refers to the north. This agrees with the Arameans' use of the two terms as well as it agrees with the Egyptians' way of thinking. He presumes that Yaho Temple is a sort of Church lying one street behind Khnum outskirts, but this is not archeologically proved. Hence, he suggested to seek for the site of the Jewish Temple further north, as Rubensohn did. Kraeling came to the conclusion that delimiting the site of Jewish Tempe was considered unproved. 
As the alleged temple was uprooted and its existence was never proved, so was the name Yaho as the God of the Jews never mentioned in the Aramaic Papyri of Elphantine. What was mentioned as God was (yhh, Cowley $13^{14}$ ). The name was distorted to Yaho to agree with the name Yeho mentioned in the Old Testament as a beginning of names like Yehoshafat. Though there is a difference between the two lies in the stress (namely Yâho, Yehô). As to the explanation of Yhh Sb't which was mentioned in an ostracum of Elphantine (found by Clermont Ganneau) that it was Yahweh "God of troops", it conflicts with matching the phonological units. The name Yeho mentioned in the papyri (Cowley $22^{1}$ ) might be an earlier form of the God's name, but it is not in any way an abridged form of Yahaweh.

Another names of God were mentioned in the papyri and these are names of Semitic deities. For example Allah (Cowley 306) (CF Arabic Allah), Allah Shmaya (Cowley $30^{2}$ ) God of Heavens.

There are other names ending with Bethel as "Anath bethel (Cowley $22^{125}$ ), Ishmubethel (Cowley $22^{124}$ ). In the Pentateuch it was admitted that Bethel was an ancient Cannanite God (CF Genesis $31^{13}$ ).

In Jewish community, offerings were supposed to be offered by any of Aaron's sons or any of the Levites, but in the Aramaic Papyri of Elphantine there was neither a mention of Aaron nor of the levites, nor even a hint that the Jewish community of Elphantine ever heard of the house of Aaron (Cowley XXII).

In the Aramaic Papyri of Elphantine, there was no mention of a prophet called Moses, Exodus, any of the prophets of the children of Israel, any claim of Judah land, names belong to ancient Jewish history, as it is the case in the Pentateuch and ancient history (Cowley XXIII), observing the Sabbath, celebrating any of the Jew's feasts. But the one feast assumed by Cowley (namely Passover) goes back to his conjuncture in reading the papyrus (Cowley 21). He guessed reading three whole broken and lost lines (4 to 6) as follows: "In the month of Tybi let there be a Passover for the Jewish garrison. Now you accordingly count fourteen days of the month Nisan and keep the Passover and from the $15^{\text {th }}$ day to the $21^{\text {st }}$ day of Nisan are seven days of unleavened bread". He also guessed reading the name of the King as Darius. 
Reading broken and lost lines came as a result of more guessing in order to befit the occurrence of Passover and the unleavened break feast in the Pentateuch. As long as there was no accurate mention of Passover and unleavened bread feast in the papyrus (21), this assumed reading cannot be acceptable.

Researchers who relate the Aramaic Papyri of Elphantine to the Jewish community there based their claim on a verse stated in the Pentateuch "An Aramean ready to perish was my father" (Deuteronomy $26^{5}$ ). Consulting Gesenius Lexicon we find Aram as a son of Sam and a brother of Arphaxed who begat Shalah who begat Eber father of Hebrews. This leads to the question how come that Aram was the brother of Eber's grand father and Eber's father in the same time.

Aram is also a name derived from Rum in the sense of highness. In a cuniform inscription belonging to the $23^{\text {rd }}$ century B. C. Aram was mentioned as a high place in Mesopotemia. Hence its name was derived from highness.

As if these researchers accept to abandon their Jewish identity and adopt instead the Aramaic identity for the aim of ascribing the Aramaic papyri to the Jewish community of Elphantine.

Cowley's statement that the Aramaic language of Elphantine Papyri resembles the Aramaic language of the Book of Ezra (Old Testament) might be refuted as follows: The text mentioned in Ezra $4^{7-}$ was the letter which Bishlam and his companions wrote to Artaxerxes the Persian king in Aramaic language. That is to say that the king used to read Aramaic language as it was an international tongue during the Persian reign, and in order to reach an understanding the letter was introduced to him in an Aramaic translation. This proves that the Aramaic tongue of the Book of Ezra was performed by a translator, not necessarily Jewish.

As to Cowley's statement that the Aramaic language of the present Papyrus (Cowley 15) resembles that of the Book of Ezra, matching the two languages leads to the conclusion that they are two different tongues. The former belongs to Egyptian Aramaic papyri, the latter belongs to Biblical Aramaic. 
Baumgartner attained that the Aramaic documents of the Book of Ezra were more recent than the Aramaic Papyri of Elphantine (Kraeling P. 7). This means that the Aramaic papyri of Elphantine which belongs to ancient Aramaic (Egyptian Aramaic as stated above) is historically older than the Aramaic of the book of Ezra. Hence they belong to absolutely two different periods of language.

Those who spoke Aramaic in the Old Testament (Daniel $2^{4-}$ ) were not Hebrews but Chaldeans whose language was called Chaldeac Aramaic. Yet the modern Semitic studies, with the aim of relating the Aramaic Papyri to Jewish community in Elphantine, abandoned the name Chaleac and put instead the name Aramaic, which remains uptil now as the Biblical Aramaic and very different form Aramaic language of papyri and Ostraca (ancient/ Egyptian Aramaic).

The Aramaic Papyri of Elphantine used the term "Masgeda" as a place of worship i.e. mosque (Arabic Masged). Hence, if their composer was a Jew, he would have used the Jewish term "temple" as a place of worship noting that Cowley put in $44^{3}$ the translation "temple" for the term "masgeda" (mosque). The same papyrus used the Aramaic name for God "Allaha" (Arabic Allah) when swearing by God. Mibtahiah (Cowley 14 $4^{5}$ ) swore by the godess Sati who was connected with worshipping Khnum in the Egyptian temple and did not swear by God of Jews. Cowley maintained that she swore by Sati because the adversary was Egyptian (P. 43).

Further Proof of relating Aramaic Papyri of Elphantine to Aramean community there might be considered in view of Kraeling perplexity (P. 38) towards the non existence of Jewish names in lists of participants to the temple-in accordance with their membership-in both ostraca of Elphantine and of Clermont Ganneau, as the former includes only Semitic names while the latter includes only Egyptian names. Noting that the list mentioned in Cowley (24) counting the members of Elphantine garrison and dealing with rations bestowed to soldiers, stated names of none Jewish origin (except once i.e. Haggai b. Shemc'iah).

Pretext of researchers that the habit of folding documents after inscribing and sealing prevailed among the Jewish community in Elphantine might be disproved due to the fact that same habit prevailed also among the 
Arameans of Elphantine. Hence this could not be considered as a proof to relate the Aramaic papyri of Alphantine to the Jewish community there.

Cowley disregarded the lacunae $\left(15^{1}\right)$ which necessitate reading "Tishritu" as the name of the Babylonian month and misread it "Tishri" as the name of Jewish month in order to coincide with Jewish calendar. Though there was no mention at all of Jewish calendar in the Aramaic papyri of Elphantine, but only of Babylonian and Egyptian Calendars.

Cowley also disregarded the lacuna at the end of the Aramaic Word "Be'adtha" (congregation: $\left(15^{22,26}\right)$ which necessitates reading the word in its Aramaic form. He misread it as "Be-edah" regarding it as a Hebrew word meaning "congregation" in order to coincide with the idea of relating Aramaic Papyri of Elphantine to Jewish Community there. 


\section{References:}

- P. Ayyad, Arameans in Egypt, Cairo, 1975

- Brown, F., Driver S.R., Briggs Ch., Hebrew and English Lexicon of the Old Testament, Oxford, 1907-1966.

- Cowley Aramaic Papyri of the fifth century B. C., Oxford, 1923.

- Kraeling, Emil, G., The Brooklyn Museum Aramaic Papyri (Fifth Century B. C.), London, Oxford, 1970.

- Sayce, Cowley, Aramaic Papyri discovered at Aswan, London, 1906. 